\title{
Determinants of Bank Liquidity in Nepal
}

\author{
Raghu Bir Bista* \& Priyanka Basnet \\ Department of Economics Tribhuvan University, Nepal
}

\begin{abstract}
This paper examines determinants of bank liquidity of the commercial bank in Nepal based on 12 years long time series data base from 2004 to 2015, employing the econometric model. As a result, the bank liquidity of the commercial bank has fluctuation and instable trend line indicating the risk of liquidity crunch. Similarly, deposit, capital adequacy, remittance and bank size are determinants of bank liquidity of the commercial bank out of which deposit is prevalent to increase bank liquidity and capital adequacy is a key to decrease it. In long term, capital adequacy, bank size and government expenditure increase bank liquidity of the commercial bank but deposit decreases it. Thus, internal variables influence bank liquidity more than macroeconomic variables. Therefore, the commercial banks should maintain bank liquidity in short period and in long period for achievement of financial health, stability and growth as per mention regulatory provisions and criteria of the monetary policy and the monetary policy should be formulated to maintain short and long term bank liquidity in accordance with IMF standards and guidelines for reducing the potential risk of liquidity crunch as result of the variation of macro-economic variables and of international global trade and oil price and production.
\end{abstract}

Keywords: Bank liquidity, Liberalization, Commercial Banks, Nepal

\section{Introduction}

Economic liberalization in the post 1990 has revolutionized banking sector as well as money market in the World, particularly in the developing world. Its example is Nepal where the three State Banks's oligopoly money market was transformed into monopolistic money market after entering 28 private and joint venture commercial banks, along with numerous finance company and more than 10000 cooperatives (Bista, 2016). The money market has become broader, wider and competitive from the city center to the rural center since then. In recent years, the commercial banks have mobilized 3300 billion NRs deposit from the people across the country and allocated 2900 billion NRs credit investment on the different heads all over the country. About 15 million population of the country have access bank services. Slowly and gradually, informal economy is being transformed into formal economy. Therefore, the entry of the private banks in money market has positive vibration with efficient and competition in financial market, along with production, consumption, trade and services.

Like as national economy, financial market has contraction and expansion in the fluctuation of demand and supply of money in financial market as per economic policy of the government. Its result is bank liquidity crunch. As per rule and regulation of the Central Bank of Nepal, the bank had a liquidity crunch in 2010, 2011, 2015 and 2018. It was not recorded once but also thrice in that year. In 2010 and 2011, liquidity ratio dropped at 15 percent from 18 percent (NRB, 2011). Again, it slipped down at 12 percent in 2018(NRB, 2018). Pant (2016) mentioned it as the failure of the

\footnotetext{
* Corresponding author.

E-mail address: bistanepal@gmail.com (Raghu Bir Bista)
}

Quantitative Economics and Management Studies (QEMS) is licensed under an Attribution-NonCommercial-ShareAlike 4.0 International (CC BY-NC-SA 4.0) 
government to spend development budget, slipped down remittance, deposit and export income, 40 billion NRs withdraw of taxpayer's tax file, huge corruption to informal channel, massive growth of import trade and its bills. Such type of fluctuation is natural but the bank should maintain the bank liquidity as required to minimize the undesired potential instability with excessive demand of credit in the financial market. Its result was declining credit expansion, inclining interest rate, increasing the cost of production and reduction in credit to productive sector (Pant, 2016). In 2011, the average rate of interest on deposit jumped at 6 percent. In 2018, it again reached at 5.5 percent. Its negative implication was the growth of credit interest rate. Therefore, the central bank of Nepal has used open market operation to supply money in the banks so that the banks can use bank liquidity as an instrumental determinant to maintain shocks, puzzles and bubbles in money demand for investment, transaction and speculative motives. Therefore, bank liquidity is important variable to determine the liquidity of the economy, particularly the liquidity of financial market.

Bank liquidity relates to the capacity of the bank to meet expected and unexpected liquidity from the business community and the public. By nature and character, it is instable because the bank has an obligatory to collect small and small resources deposit for short term but to finance big investment for medium and long term. For transaction and precautionary situation, bank liquidity has soft risk. If it is managed, it will be profitable. If not, it will be in risk. Since like in the national economy, the financial market has also expected and unexpected shocks and bubbles from the budgetary policy as well as monetary policy, along with natural and manmade disasters and wave of liberalization and globalization, the fluctuation of bank liquidity results to liquidity risk in short and long term. In general, there are two major risks: funding liquidity risk and market liquidity risk. Theoretically, these two risks are measured by liquidity gap and liquidity ratios, like as bank liquidity.

Determinants of bank liquidity have two schools of thoughts in literatures. First school of thought literatures (Aspachs et al. (2005), Moore (2010), Bonfim and Kim (2011), Chagwiza (2011), Tesfaye 2012), Choon et al. (2013), Malik and Rafique (2013), Vodova (2013), Chagwiza (2014), Horvath et al. (2014), Melese and Laximikantham (2015), Moussa (2015), Sheefeni and Nyambe (2016) and Singh and Sharma (2016)) argue internal specific factors and macroeconomic variables as determinants of bank liquidity of the commercial banks with their empirical evidences of UK, Latin America and Caribbean, Ethiopia, India, Zimbabwe etc. In these literatures, internal and macro-economic variables are capital adequacy, share of non-performing loans, loan growth, GDP growth rate, interest rate, bank size, etc. Out of these variables, some have positive relationship with bank liquidity of the commercial bank, some have negative. In this context, Tesfaye (2012) found capital adequacy, bank size, non-performing loans, interest rate margin and general inflation rate were the statistically significant factors affecting liquidity of commercial banks in Ethiopia. In the study, the capital adequacy had positive and statistically significant impact on liquidity at 10 percent level meanwhile bank size, interest rate margin and inflation rate had positive and significant impact on liquidity at 5 percent level. Similarly, at 1 percent level, non-performing loans had positive and statistically significant influence on banks liquidity. However, loan growth, real GDP growth rate and short-term interest rate were statistically insignificant. Similarly, in Namibia, Sheefeni and Nyambe (2016) found GDP as the main determinant of the bank liquidity of the commercial bank and the positive relationship with monetary policy but negative with inflation.

However, the second school of thought literatures (Bonfim and Kim (2011), Ferrouhi and Abderrassoul (2013) and Feng (2017)) advocates internal and external variables as determinants of bank liquidity of the commercial banks with their country specific empirical evidences of Europe and China. In this literatures, there were used bank size, share of own bank's capital, external funding, foreign assets, FDI etc.

In Nepal, there are handful literatures (Subedi and Neupane, 2013; Gautam, 2016 and Ojha, 2018) focusing on the determinants of bank liquidity in the commercial banks of Nepal. Subedi and Neupane (2013) studied on this issue six commercial banks sample by using multivariate linear regression model based on 10 years' time series data set from 2002 to 2012. The study found capital adequacy and share of non-performing loans had a negative and statistically significant effect on the bank liquidity of the commercial banks whereas loan growth, GDP growth rate, liquidity premium and short term interest rates had a negative and statistically insignificant effect on the bank liquidly of the commercial bank. Similarly, bank size had a positive and a statistically significant effect and the inflation rate had a positive but insignificant effect on the bank liquidity of the commercial banks. Similarly but differently, Gautam (2016) studied 10 commercial banks of Nepal using multivariate variables based on 11 years data sets from 2005 to 2014 by using least square regression model. His findings contradicted with Subedi and Neupane (2013) with the 
result that bank size, capital adequacy and inflation rate had a positive impact on bank liquidity but non-performing loans, profitability and GDP growth rate had negative impact on bank liquidity of the commercial banks. Statistically, capital adequacy, non-performing loan and profitability were significant but bank size, GDP growth rate and inflation rate were insignificant. The study concluded capital adequacy, non-performing loan, bank size, profitability, GDP growth rate and inflation rate as determinants of bank liquidity of the commercial banks. Similarly, Ojha (2018) studied the influence of NPL, return on assets, CAR, return on equity, GDP, inflation and interbank rate on bank liquidity of the commercial bank by employing panel data from 2010 to 2016 by using multiple regression model. The study found the influence of ROA, ROE, NPL, GDP and IBR on bank liquidity of the commercial banks. Above literatures are very few on this issue with mixed results and contradicted each other based on only 10 years leaving important variables. This study is relevant to fill the gap of above literatures.

This study examines whether bank liquidity trend is positive and whether factors affecting the bank liquidity of the commercial banks. Its outputs would be valuable to new monetary policy of the country.

The main objective of the study is to examine the economic liberalization and its impact on liquidity in the commercial banks of Nepal. Its specific objectives are as follows: a) measure the status and trend of liquidity in the commercial banks, b) examine its determinants and liquidity in the commercial banks and c) explore its issues and policy implications.

\section{Materials and Methods}

\subsection{Theoretical Framework}

Literatures (Aspachs et al. (2005), Moore (2010), Bonfim and Kim (2011), Chagwiza (2011), Tesfaye 2012), Choon et al. (2013), Malik and Rafique (2013), Vodova (2013), Audo(2014) Chagwiza (2014), Horvath et al. (2014), Mehmet (2014), Melese and Laximikantham (2015), Moussa (2015), Sheefeni and Nyambe (2016) and Singh and Sharma (2016)) argue the bank liquidity as determined by internal and macro-economic variables. In internal variable, there are NPL, capital adequacy, bank size, non-performing loan, profitability, etc. whereas in macroeconomic variables, there are GDP (Gross Domestic Product), Inflation, Unemployment, etc. Its theoretical function is as (1).

$$
\mathrm{Y}_{\mathrm{bl}}=f\left(\mathrm{X}_{\mathrm{iv}}, \mathrm{X}_{\mathrm{mv},}, \varepsilon\right)
$$

where:

$\mathrm{Y}_{\mathrm{bl}}=$ bank liquidity of the commercial banks (liquidity ratio);

$\mathrm{X}_{\mathrm{iv}}=$ internal variable (deposit ratio, Capital Adequacy, Bank size, etc.);

$\mathrm{X}_{\mathrm{mv}}=$ macro variable (Inflation rate, Deposit to Money Supply, Government Expenditure, Remittance inflow \& Public Debt to GDP ratio);

$\varepsilon=$ error.

\subsection{Econometric Model}

Above theoretical function equation (i) is expanded and transformed into multiple regression econometric models. In this model, liquidity ratio (bank liquidity) $L I Q_{i t}$ is dependent variable whereas the proportion of Deposit of $\mathrm{i}^{\text {th }}$ bank $\left(D E P_{i t}\right)$, Capital Adequacy of $i^{\text {th }}$ bank $\left(C A_{i t}\right)$, Bank Size of $\mathrm{i}^{\text {th }}$ bank $\left(S I Z E_{i t}\right)$, Inflation Rate $\left(I N F_{t}\right)$, Deposit to Money Supply $\left(D M S_{t}\right)$, Remittance inflow $\left(R E M_{t}\right)$ and Public Debt to GDP ratio $\left(P D_{t}\right)$ are independent. There are There are eight estimators: $\beta, \beta_{1}, \beta_{2}, \beta_{3}, \beta_{4}, \beta_{5}, \beta_{6}, \beta_{7}$, and $\beta_{8}$. Based on above theoretical equation (1), multiplier econometric model (2) is built as:

$$
L I Q_{i t}=\alpha_{i t}+\beta_{1} D E P_{i t}+\beta_{2} C A_{i t}+\beta_{3} S I Z E_{i t}+\beta_{4} I N F_{i t}+\beta_{5} D M S_{t}+\beta_{6} G_{E X P t}+\beta_{7} R E M_{t}+\beta_{8} P D_{t}+\varepsilon_{i t}
$$

Where:

$L I Q_{i t}=$ liquidity ratio of $\mathrm{i}^{\text {th }}$ bank on year $t$;

$D E P_{i t}=$ deposit of $\mathrm{i}^{\text {th }}$ bank on year $\mathrm{t}$; 
$C A_{i t}=$ capital adequacy of $\mathrm{i}^{\text {th }}$ bank on year $\mathrm{t}$;

$S I Z E_{i t}=$ bank size of $\mathrm{i}^{\text {th }}$ bank on year $\mathrm{t}$;

$I N F_{t}=$ inflation rate in Nepal in year $\mathrm{t}$;

$D M S_{t}=$ deposit to money supply of Nepal in year t;

$G E X P_{t}=$ government expenditure of Nepal in year $\mathrm{t}$;

$R E M_{t}=$ remittance inflow of Nepal in year $\mathrm{t}$;

$P D_{t}=$ public debt to GDP ratio of Nepal in year $\mathrm{t}$;

$B=$ coefficients of the variables;

$\alpha=$ constant;

$\varepsilon_{\mathrm{it}}=$ is random error term.

Data nature of all above independent and dependent variables: liquidity ratio (bank liquidity) $L I Q_{i t}$, Deposit of $\mathrm{i}^{\text {th }}$ bank $\left(D E P_{i t}\right)$, Capital Adequacy of $\mathrm{i}^{\text {th }}$ bank $\left(C A_{i t}\right)$, Bank Size of $\mathrm{i}^{\text {th }}$ bank $\left(S I Z E_{i t}\right)$, Inflation Rate $\left(I N F_{t}\right)$, Deposit to Money Supply $\left(D M S_{t}\right)$, Remittance inflow $\left(R E M_{t}\right)$ and Public Debt to GDP ratio $\left(P D_{t}\right)$ is 15 time series from 2002 to 2018 collected from Nepal Rastra Bank. Its data analysis is done by using Excel and SPSS.

\section{Result}

\subsection{Result I: Trend Analysis of Bank Liquidity of the Commercial Bank (2003-2018)}

Figure 1 presents annual trend analysis of liquidity from 2004 to 2018 . This liquidity is ratio with total assets of the commercial bank. X-axis represents to time period from 2004 to 2018 whereas $\mathrm{Y}$-axis represents to percent (\%). In this way, liquidity to total assets ratio is independent meanwhile time period is dependent variable. The trend line depends on mean, standard deviation and variation. Over 15 years, there is variation of the liquidity of the commercial bank.

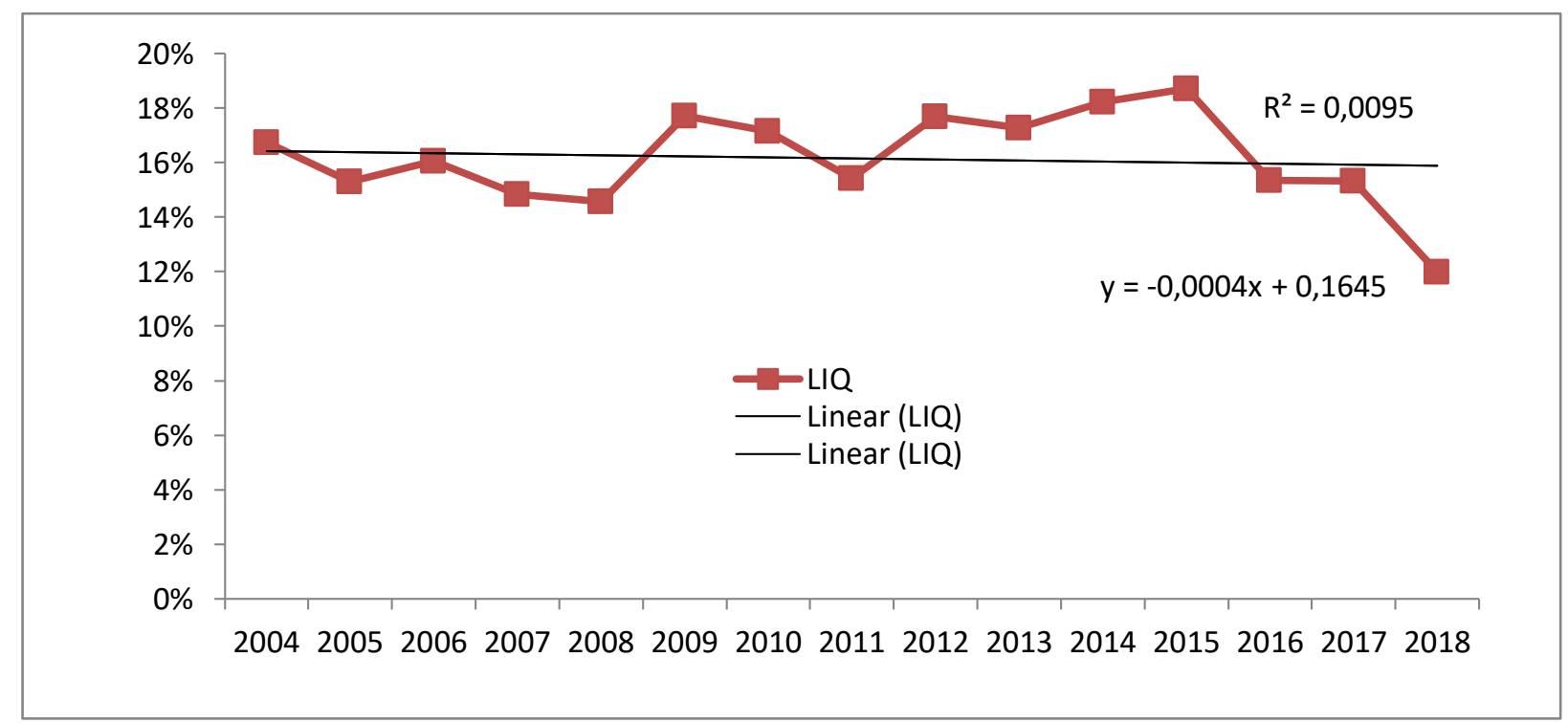

Source: $N R B, 2018$

Fig. 1 Annual Trend Analysis of Liquidity (Liquid to Total Assets) 


\subsection{Result II: Factors influencing Bank Liquidity of the Commercial Banks}

Table 1 presents mean, standard deviation, minimum and maximum of key variables resulted from above model. In Table 1 , column 1 presents 10 variables in which liquidity ratio (bank liquidity) LIQ $_{i t}$ is dependent variable whereas the proportion of Deposit of $i^{\text {th }}$ bank $\left(\mathrm{DEP}_{\mathrm{it}}\right)$, Capital Adequacy of $i^{\text {th }}$ bank $\left(\mathrm{CA}_{\mathrm{it}}\right)$, Bank Size of $i^{\text {th }}$ bank $\left(\mathrm{SIZE}_{\mathrm{it}}\right)$, Inflation Rate $\left(\mathrm{INF}_{t}\right)$, Deposit to Money Supply $\left(\mathrm{DMS}_{t}\right)$, Remittance inflow $\left(\mathrm{REM}_{\mathrm{t}}\right)$ and Public Debt to GDP ratio $\left(\mathrm{PD}_{\mathrm{t}}\right)$ are independent. Standard deviations of these variables from mean are no so far significant. The mean of above variables represents properly 175 observations from time series (2003-2018).

Table 1. Descriptive Statistics

\begin{tabular}{ccccc}
\hline Variable & Mean & Std. Dev. & Min & Max \\
\hline LIQ1 & 0.11 & 0.02 & 0.08 & 0.16 \\
LIQ2 & 0.76 & 0.06 & 0.63 & 0.89 \\
DEP & 0.72 & 0.08 & 0.59 & 0.82 \\
CA & 0.05 & 0.02 & 0.02 & 0.07 \\
SIZE & 13.84 & 0.64 & 12.84 & 15.04 \\
INF & 7.69 & 2.77 & 2.022 & 13.76 \\
DMS & 1.26 & 0.07 & 1.13 & 1.65 \\
GEXP & 11.21 & 1.39 & 4.89 & 13.87 \\
REM & 10.08 & 0.82 & 8.49 & 11.38 \\
PD & 5.57 & 4.64 & 0 & 11.88 \\
\hline
\end{tabular}

Internal and Macro Variables influencing Bank Liquidity in terms deposit ratio (LIQ1) and loan to deposit ratio (LIQ2)

Table 2 presents results of multi regression econometric model of dependent variable, liquidity ratio (bank liquidity) LIQ $_{i t}$ whereas the proportion of Deposit of $i^{\text {th }}$ bank $\left(D E P_{i t}\right)$, Capital Adequacy of $i^{\text {th }}$ bank $\left(\mathrm{CA}_{i t}\right)$, Bank Size of $i^{\text {th }}$ bank $\left(\mathrm{SIZE}_{\mathrm{it}}\right)$, Inflation Rate $\left(\mathrm{INF}_{\mathrm{t}}\right)$, Deposit to Money Supply $\left(\mathrm{DMS}_{\mathrm{t}}\right)$, Remittance inflow $\left(\mathrm{REM}_{\mathrm{t}}\right)$ and Public Debt to GDP ratio $\left(\mathrm{PD}_{\mathrm{t}}\right)$ are independent. Internal and Macro Variables influencing Bank Liquidity in terms deposit ratio (LIQ1). There are There are eight estimators: $\beta, \beta_{1}, \beta_{2}, \beta_{3}, \beta_{4}, \beta_{5}, \beta_{6}, \beta_{7}$, and $\beta_{8}$.

In the results of the econometric model, parameter $(\beta)$ represents constant, $\beta_{1}$ as marginal change of deposit of ith bank (DEPit), $\beta_{2}$ as marginal change of capital adequacy of ith bank (CAit), $\beta_{3}$ as marginal change of bank Size of ith bank (SIZEit), $\beta_{4}$ as marginal change of Inflation Rate (INFt), $\beta_{5}$ as marginal change of Deposit to Money Supply (DMSt) , $\beta_{6}$ marginal change of Government expenditure, $\beta_{7}$ marginal change of Remittance inflow(REMt) and $\beta_{8}$ marginal change of Public Debt to GDP ratio(PDt).

Table 3 presents results of multi regression econometric model of dependent variable, loan deposit ratio (bank liquidity) $\mathrm{LIQ}_{\mathrm{it}}$ whereas the proportion of Deposit of $i^{\text {th }}$ bank $\left(\mathrm{DEP}_{\mathrm{it}}\right)$, Capital Adequacy of $i^{\text {th }}$ bank $\left(\mathrm{CA}_{\mathrm{it}}\right)$, Bank Size of $i^{\text {th }}$ bank $\left(\mathrm{SIZE}_{\mathrm{it}}\right)$, Inflation Rate $\left(\mathrm{INF}_{\mathrm{t}}\right)$, Deposit to Money Supply $\left(\mathrm{DMS}_{\mathrm{t}}\right)$, Government Expenditure $\left(\mathrm{GE}_{\mathrm{it}}\right)$ Remittance inflow $\left(\mathrm{REM}_{\mathrm{t}}\right)$ and Public Debt to GDP ratio $\left(\mathrm{PD}_{\mathrm{t}}\right)$ are independent. Internal and Macro Variables influencing Bank Liquidity in terms deposit ratio (LIQ1). There are eight estimators: $\beta, \beta_{1}, \beta_{2}, \beta_{3}, \beta_{4}, \beta_{5}, \beta_{6}, \beta_{7}$, and $\beta_{8}$.

In the results of the econometric model, parameter $(\beta)$ represents constant, $\beta_{1}$ as marginal change of deposit of $i^{\text {th }}$ bank $\left(D P_{i t}\right), \beta_{2}$ as marginal change of capital adequacy of $i^{\text {th }}$ bank $\left(\mathrm{CA}_{\mathrm{it}}\right), \beta_{3}$ as marginal change of bank size of $\mathrm{i}^{\text {th }}$ bank $\left(\operatorname{SIZE}_{\mathrm{it}}\right), \beta_{4}$ as marginal change of Inflation Rate $\left(\mathrm{INF}_{\mathrm{t}}\right), \beta_{5}$ as marginal change of Deposit to Money Supply $\left(\mathrm{DMS}_{\mathrm{t}}\right), \beta_{6}$ marginal change of Government expenditure, $\beta_{7}$ marginal change of, remittance inflow $\left(\mathrm{REM}_{\mathrm{t}}\right)$ and $\beta_{8}$ marginal change of public debt to GDP ratio( $\left(\mathrm{PD}_{\mathrm{t}}\right)$. 
Table 2. Results of Regression Model

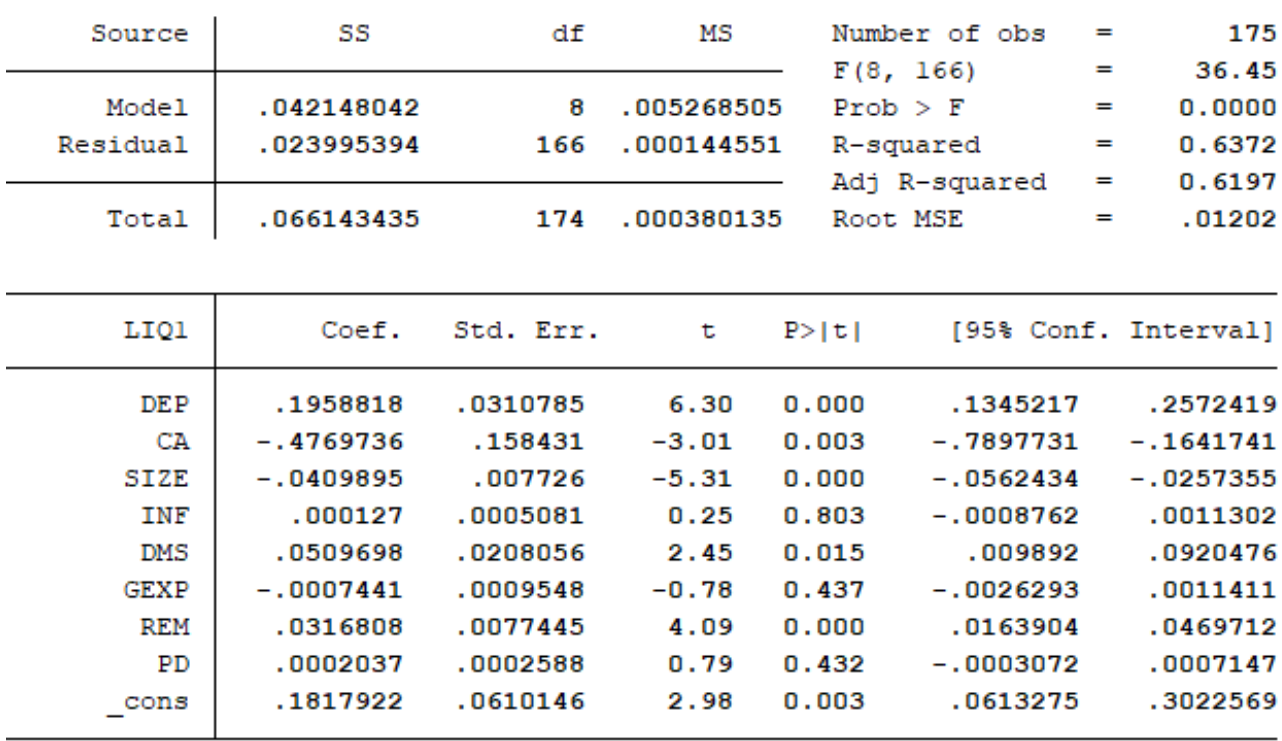

Table 3. Results of Regression Model

\begin{tabular}{|c|c|c|c|c|c|c|}
\hline Source & sS & $d f$ & MS & Number of obs & $=$ & 175 \\
\hline Model & .527869403 & 8 & .065983675 & Prob > F & $=$ & 0.0000 \\
\hline Residual & .048327405 & 166 & .000291129 & R-squared & $=$ & 0.9161 \\
\hline Total & .576196808 & 174 & .003311476 & $\begin{array}{l}\text { Ad] R-Squared } \\
\text { Root MSE }\end{array}$ & $=$ & $\begin{array}{l}0.9121 \\
.01706\end{array}$ \\
\hline
\end{tabular}

\begin{tabular}{r|rrrrrr}
\hline LIQ2 & Coef. & Std. Err. & $t$ & P $>|t|$ & [95\% Conf. Interval] \\
\hline DEP & -.4802096 & .0441055 & -10.89 & 0.000 & -.5672897 & -.3931295 \\
CA & 2.459415 & .2248397 & 10.94 & 0.000 & 2.015501 & 2.903329 \\
SIZE & .0771429 & .0109645 & 7.04 & 0.000 & .0554951 & .0987907 \\
INF & -.0011512 & .0007211 & -1.60 & 0.112 & -.0025749 & .0002725 \\
DMS & -.0123545 & .0295266 & -0.42 & 0.676 & -.0706506 & .0459416 \\
GEXP & .0058885 & .0013551 & 4.35 & 0.000 & .0032132 & .0085639 \\
REM & -.0080051 & .0109907 & -0.73 & 0.467 & -.0297047 & .0136945 \\
PD & -.0009937 & .0003673 & -2.71 & 0.008 & -.0017188 & -.0002685 \\
Cons & -.0411104 & .0865898 & -0.47 & 0.636 & -.2120697 & .1298488 \\
\hline
\end{tabular}

\section{Discussion}

Above results of the trend analysis and the econometric model provides strong evidence on bank liquidity of the commercial bank. Trend line of bank liquidity of the commercial bank over 15 years from 2004 to 2018 is fluctuation, 
instable and declining. Over 15 years, mean bank liquidity of the commercial banks is 16 percent. In 2005, 2007, 2008, 2011, 2016, 2017 \& 2018, bank liquidity was below mean but in 2009, 2010, 2012, 2013, 2014 \& 2015, it was above mean. Thus, over 15 years, there is variation of the bank liquidity of the commercial bank. Trend analysis shows -.0004 percent negative growth of bank liquidity of the commercial banks. There may be internal and macroeconomic variables behind such variation of trend line. It indicates the risk of bank liquidity in the commercial bank, liquidity crunch.

Above results of the trend analysis provides strong evidence on bank liquidity of the commercial bank. Trend line of bank liquidity of the commercial bank over 15 years from 2004 to 2018 is fluctuation, instable and declining. Over 15 years, mean bank liquidity of the commercial banks is 16 percent. In 2005, 2007, 2008, 2011, 2016, 2017 \& 2018, bank liquidity was below mean but in 2009, 2010, 2012, 2013, 2014 \& 2015, it was above mean. Thus, over 15 years, there is variation of the bank liquidity of the commercial bank. Trend analysis shows -.0004 percent negative growth of bank liquidity of the commercial banks. There may be internal and macro-economic variables behind such variation of trend line. It indicates the risk of bank liquidity in the commercial bank, liquidity crunch.

Furthermore, above results of the econometric regression model provides sufficient and strong evidence on coefficient of independent variable, the bank liquidity of the commercial bank. Its descriptive statistics of dependent variable, bank liquidity $\left(L I Q_{i t}\right)$ and independent variables including the proportion of Deposit of $\mathrm{i}^{\text {th }}$ bank $\left(D E P_{i t}\right)$, Capital Adequacy of $\mathrm{i}^{\text {th }}$ bank $\left(C A_{i t}\right)$, Bank Size of $\mathrm{i}^{\text {th }}$ bank $\left(S I Z E_{i t}\right)$, Inflation Rate $\left(I N F_{t}\right)$, Deposit to Money Supply $\left(D M S_{t}\right)$, Remittance inflow $\left(R E M_{t}\right)$ and Public Debt to GDP ratio $\left(P D_{t}\right)$.

Bank liquidity of the commercial banks $\left(L I Q_{i t}\right)$ includes liquid assets to total assets as $L I Q_{1}$ and credit to deposit ratio as $L I Q_{2}$. Based on 175 observations, mean of $\mathrm{LIQ}_{1}$ is 11 percent but mean of $\mathrm{LIQ}_{2}$ is 76 percent. Their standard deviations have just slight dispersion from their mean values. In case of $\mathrm{LIQ}_{2}, 5$ percent standard deviation shows more dispersion than $\mathrm{LIQ}_{1}$. The maximum and minimum values of $\mathrm{LIQ}_{1}$ are 16.4 percent and 7.8 percent respectively, whereas the maximum and minimum values of $\mathrm{LIQ}_{2}$ are 63 percent and 89 percent respectively. Despite their variation and instable, $\mathrm{LIQ}_{1}$ and $\mathrm{LIQ}_{2}$ are positive. In case of $\mathrm{LIQ}_{2}$, the loans to deposit ratio is nearly international standard.

Independent variables among which capital adequacy $\left(\mathrm{CA}_{\mathrm{it}}\right)$, all reaming variables the deposit of $\mathrm{i}^{\text {th }}$ bank $\left(\mathrm{DEP}_{\mathrm{it}}\right)$, bank size of $i^{\text {th }}$ bank $\left(\mathrm{SIZE}_{\mathrm{it}}\right)$, inflation rate $\left(\mathrm{INF}_{\mathrm{t}}\right)$, deposit to money supply $\left(\mathrm{DMS}_{\mathrm{t}}\right)$, remittance inflow $\left(\mathrm{REM}_{\mathrm{t}}\right)$ and public debt to GDP ratio $\left(\mathrm{PD}_{\mathrm{t}}\right)$ are in disperse. Dispersion of public debt to GDP ratio $\left(\mathrm{PD}_{\mathrm{t}}\right)$ is 4.64 followed by inflation with 2.77, government expenditure (GEXP) with 1.39, remittance inflow $\left(\mathrm{REM}_{\mathrm{t}}\right)$ with 0.82 , bank size $\left(\right.$ Size $\left._{i t}\right)$ with 0.64, deposit (DEP) with 0.08 and deposit to money Supply $\left(\mathrm{DMS}_{\mathrm{t}}\right)$ with 0.07 .

Estimation of coefficient explains how much change of bank liquidity (liquid assets to total assets ratio) (LIQ ${ }_{1}$ ) by internal and macro-economic variables: the change of capital adequacy $\left(\mathrm{CA}_{\mathrm{it}}\right)$, the deposit of $\mathrm{i}^{\text {th }}$ bank $\left(\mathrm{DEP} \mathrm{i}_{\mathrm{it}}\right)$, bank size of $i^{\text {th }}$ bank $\left(\mathrm{SIZE}_{\mathrm{it}}\right)$, inflation rate $\left(\mathrm{INF}_{\mathrm{t}}\right)$, deposit to money supply $\left(\mathrm{DMS}_{\mathrm{t}}\right)$, remittance inflow $\left(\mathrm{REM}_{\mathrm{t}}\right)$ and public debt to GDP ratio $\left(\mathrm{PD}_{\mathrm{t}}\right)$. In the result of the model, $\mathrm{R}^{2}$ value is 0.62 . It means approximately 62 percent variation of bank liquidity explained by the above model. There is still 38 percent error term that is the different unexplained variables. It is also higher goodness to fit. The regression F-statistic takes a value 36.45. F-statistics tests the null hypothesis that all of the slope parameters $\left(\beta s^{\prime}\right)$ are jointly zero. In the above case $p$-value of zero attached to the test statistic shows that this null hypothesis should be rejected even at $1 \%$ level of significance.

As above result, deposit, capital adequacy, bank size, deposit to money supply and remittance are the statistically significant factors affecting liquidity of commercial banks. Deposit is positive and statistically significant impact on liquidity indicating a magnitude of 19 percent increase in liquidity due increase in deposit. Capital adequacy is negative and statistically significant impact on liquidity with an indication of 47 percent decrease in liquidity due to increase in capital adequacy. Bank size too is negative and significant impact on liquidity with a minimal magnitude of 4 percent decrease in liquidity due to increase in the size of the banks. Remittance is positive and statistically significant influence on banks liquidity with 3 percent increase in liquidity due to increase in remittance. Macroeconomic variables (inflation, government expenditure, and public debt) are statistically insignificant. The coefficient signs of inflation and public debt are positive though insignificant whereas government expenditure has negative, but insignificant impact on liquidity. 
Similarly, based on above results, the estimation of coefficient explains how much change of bank liquidity (loan assets to total assets ratio) $\left(\mathrm{LIQ}_{2}\right)$ by internal and macro-economic variables: the change of capital adequacy $\left(\mathrm{CA}_{\mathrm{it}}\right)$, the deposit of $i^{\text {th }}$ bank (DEP $\left.i t\right)$, bank size of $i^{\text {th }}$ bank $\left(\operatorname{SIZE}_{\mathrm{it}}\right)$, inflation rate $\left(\mathrm{INF}_{\mathrm{t}}\right)$, deposit to money supply $\left(\mathrm{DMS}_{\mathrm{t}}\right)$, remittance inflow $\left(\mathrm{REM}_{t}\right)$ and public debt to GDP ratio $\left(\mathrm{PD}_{\mathrm{t}}\right)$. In the result of the model, $\mathrm{R}^{2}$ value is 0.91 . It means approximately 91 percent variation of bank liquidity explained by the above model. There is still 9 percent error term that is the different unexplained variables. It is also higher goodness to fit. The regression F-statistic takes a value 226.65. F-statistics tests the null hypothesis that all of the slope parameters $\left(\beta \mathrm{s}^{\prime}\right)$ are jointly zero. In the above case $p$ value of zero attached to the test statistic shows that this null hypothesis should be rejected even at $1 \%$ level of significance.

As above result, deposit, capital adequacy, bank size, government expenditure, and public debt are the statistically significant factors affecting bank liquidity of commercial banks. However, deposit is negative impact on the bank liquidity $\left(\mathrm{LIQ}_{2}\right)$ of the commercial banks, whereas capital adequacy, bank size, and government expenditure are positive to bank liquidity $\left(\mathrm{LIQ}_{2}\right)$ of the commercial banks. In 1 percent marginal change of capital adequacy,, its contribution will increase by 245 percent to the bank liquidity $\left(\mathrm{LIQ}_{2}\right)$. Similarly, in 1 percent marginal change of bank size, it will increase to the bank liquidity $\left(\mathrm{LIQ}_{2}\right)$ with 8 percent meanwhile the government expenditure will increase nominally by 0.5 percent. However, deposit will decrease by 48 percent on the bank liquidity $\left(\mathrm{LIQ}_{2}\right)$ of the commercial bank. Similarly, macro-economic variables (remittance, deposits to money supply, inflation and public debt) are insignificant and negative to bank liquidity $\left(\mathrm{LIQ}_{2}\right)$ of the commercial bank.

\section{Conclusions}

This paper assess bank liquidity of the commercial banks liquid assets to total assets ratio (LIQ $)_{1}$ ) and loan assets to total assets ratio $\left(\mathrm{LIQ}_{2}\right)$ in Nepal based on 15 years long from 2004 to 2015. As a result, trend line of bank liquidity in the commercial banks is fluctuation and instable with higher variation. Its declining trend indicates the risk of bank liquidity in the commercial bank, liquidity crunch. Similarly, descriptive statistics of $\mathrm{LIQ}_{1}$ and $\mathrm{LIQ}_{2}$ reveals 11 percent mean of $\mathrm{LIQ}_{1}$ and 76 percent mean of $\mathrm{LIQ}_{2}$. In case of $\mathrm{LIQ}_{2}, 5$ percent standard deviation shows more dispersion than $\mathrm{LIQ}_{1}$. All independent variables disperse from their mean. Dispersion of public debt to GDP ratio $\left(\mathrm{PD}_{\mathrm{t}}\right)$ is 4.64 followed by inflation with 2.77, government expenditure (GEXP) with 1.39, remittance inflow $\left(\mathrm{REM}_{\mathrm{t}}\right)$ with 0.82, bank size $\left(\mathrm{Size}_{\mathrm{it}}\right)$ with 0.64, deposit (DEP) with 0.08 and deposit to money Supply $\left(\mathrm{DMS}_{\mathrm{t}}\right)$ with 0.07 . The estimation results shows that capital adequacy, bank size, deposit to money supply and remittance are statistically significant to LIQ ${ }_{1}$ but deposit, capital adequacy, bank size, government expenditure, and public debt are statistically significant to $\mathrm{LIQ}_{2}$. Except capital adequacy and bank size, other independent variables are different. Deposit is positive in $\mathrm{LIQ}_{1}$, but negative in $\mathrm{LIQ}_{2}$. Similarly, capital adequacy is negative in $\mathrm{LIQ}_{1}$ but positive in $\mathrm{LIQ}_{2}$. In short term, deposit is an important internal variable of the commercial bank to increase bank liquidity but capital adequacy decrease bank liquidity. In long term, capital adequacy, bank size and government expenditure increase bank liquidity of the commercial bank but deposit decreases it. In conclusion, internal variables influence bank liquidity more than macroeconomic variables. Therefore, the commercial banks should maintain bank liquidity in short period and in long period for achievement of financial health, stability and growth as per mention regulatory provisions and criteria of the monetary policy and the monetary policy should be formulated to maintain short and long term bank liquidity in accordance with IMF standards and guidelines for reducing the potential risk of liquidity crunch as result of the variation of macro-economic variables and of international global trade and oil price and production.

\section{Acknowledgements}

We acknowledge the department of economics, Patan Multiple Campus, Tribhuvan University. 


\section{References}

Aspachs, O, Nier, E and Tiesset, M (2005). Liquidity, banking regulation and the macro economy: Evidence on bank liquidity holdings from a panel of UK-resident banks, Bank of England Working Paper.

Bista, R.B. (2016). Economics of Nepal. Kathmandu: New Hira Books

Bonfim, D. and Kim, M. (2011). Liquidity risk in banking: Is there herding?, SSRN Electronic Journal, DOI: $10.2139 / \mathrm{ssrn} .2163547$

Chagwiza, W. (2014). Zimbabwean commercial banks liquidity and its determinants. International Journal of Empirical Finance, 2(2), 52-64.www.semanticscholar.org

Choon, L. K., Hooi, L. Y., Murthi, L., Yi, T. S., Shven, T. Y. (2013). The determinants influencing liquidity of Malaysia commercial banks, and its implication for relevant bodies: evidence from 15 Malaysian commercial banks. http://eprints.utar.edu.my

Feng, Wei (2017). Analysis of Factors Affecting Bank Liquidity, https://webofproceedings.org/proceedings_series/ESSP/FMESS\%202017/FMESS_082258.pdf

Ferrouhi, E.M. \& Lehadiri, A. (2013). Liquidity determinants of Moroccan banking industry, MPRA Paper 59888, Germany: University Library of Munich.

Melese, N., \& Laximi, K. (2015). Assessment of banks liquidity: Empirical evidence on Ethiopian commercial banks. Developing country studies, 5, 21-30.

Mohamed, A.B.M, (2015). The determinants of bank liquidity: Case of Tunisia, International Journal of Economics and Financial Issues, Econ journals, 5(1): 249-259.

Morris, S. and Shin, H (2010). Illiquidity Component of Credit Risk, , Working Paper. USA: Princeton University.

Horvath, R., Seidler, J and Weill, L., (2014). Bank capital and liquidity creation: Granger-causality evidence, Journal of Financial Services Research, 45, (3), 341-361.

Sheefeni, J, Sheefeni, P., \& Nyambe, J. M., (2016). Macroeconomic determinants of commercial banks' liquidity in Namibia. European Journal of Business, Economics and Accountancy. 4: 19-30.

Singh, A., \& Sharma, A.K. (2016).An empirical analysis of macroeconomic and bank-specific factors affecting liquidity of Indian banks (2016). Future Business Journal, 2(1), 40-53.

Subedi, S. and Neupane, B(2013) Determinants of banks' liquidity and their impact on financial performance in Nepalese Commercial Banks, unpublished thesis unpublished MBA thesis submitted to Ace Institute of Management, Pokhara University in spring, 2013.

Tesfaye, Tseganesh (2012).Determinants of Banks Liquidity and their Impact on Financial Performance: Empirical study on commercial banks in Nepal, http://etd.aau.edu.et/bitstream/123456789/2612/3/Tseganesh\%20thesis.pdf

Vodova, P.( 2011). Liquidity of Czech commercial banks and its determinants, International journal of mathematical models and methods in applied science, 5: 1060-1067. 